\title{
Toxicity of cadmium to free-living marine and brackish water nematodes (Monhystera microphthalma, Monhystera disjuncta, Pellioditis marina)
}

\author{
G. Vranken, R. Vanderhaeghen \& C. Heip \\ Marine Biology Section, Zoology Institute, State University of Ghent, Ledeganckstraat 35, B-9000 Ghent, Belgium
}

\begin{abstract}
Cadmium toxicity to 3 marine and brackish-water nematodes (Monhystera microphthalma, M. disjuncta, Pellioditis marina) was estimated under static tests. These nematodes are very resistant to cadmium poisoning. LC 50 values are extremely time-dependent; an exposure time of $96 \mathrm{~h}$ underestimates the degree of toxicity. For M. microphthalma LC 50 values decreased from $23.6 \mathrm{ppm}$ after $96 \mathrm{~h}$ to $5.4 \mathrm{ppm}$ after $312 \mathrm{~h}$. For $M$. disjuncta LC 50 values were 21.2 and $18.4 \mathrm{ppm}$ after 192 and $264 \mathrm{~h}$ respectively. $P$. marina was much more tolerant to cadmium in comparison with the monhysterids and had LC 50 values of $90.5 \mathrm{ppm}$ at 120 , and of $77.0 \mathrm{ppm}$ at $192 \mathrm{~h}$. It is argued that MEC (minimum effective concentrations) values are ecologically more meaningful than LC 50 values, and that the former levels can be used as indicators of intolerable thresholds in the field. MEC values based on mortality and on a developmental assay in which success in attaining the adult stage was studied, turned out to be very similar. The developmental assay takes less time than the survival assays and the slope of the response curve can be used as a parameter for describing species sensitivity.
\end{abstract}

\section{INTRODUCTION}

In the last decade, numerous studies were published on effects of heavy metals on marine invertebrates. Throughout these studies one frequently encounters problems of application and evaluation of acute toxicity tests. A serious problem concerns the time limitation of these tests. Some studies (e.g. Brown \& Ahsanullah 1971, Best \& Morita 1983) indicate that for certain heavy metals the conventional $96 \mathrm{~h}$ tests are too short to determine acute toxicity effects adequately. Ahsanullah et al. (1981) suggest that even a period of $14 \mathrm{~d}$ is insufficient for completing meaningful acute lethal tests of cadmium, zinc and copper on the marine shrimp Callianassa australiensis. Nimmo et al. (1977) report for pink shrimp Penaeus duorarum a decrease in LC 50 values from 3.5 to $0.72 \mathrm{mg} \mathrm{Cd} \mathrm{l}^{-1}$ after 4 and $30 \mathrm{~d}$ respectively. In a test on grass shrimp Palaemonetes vulgaris, the same authors found a significant decrease in LC 50 values from 0.76 to $0.12 \mathrm{mg} \mathrm{Cd}^{-1}$ after 4 and 29 d respectively. Hoppenheit \& Sperling (1977) used experimental periods of $30 \mathrm{wk}$ to trace lethal effects of cadmium on populations of the harpacticoid copepod Tisbe holothuriae. These values show that median lethal threshold concentrations for some metals are time-dependent. However, prolongation of experiments does not fit the requirements for a routine standardized laboratory toxicity test.

It is generally admitted that whereas studies on lethal toxicities offer a quantifiable measure of heavy metal toxicity, they also hide valuable information on sub-lethal effects manifesting themselves in changed population dynamics. Possible effects on generation time, metal accumulation in consecutive generations, impairment of reproduction etc. at relatively low test concentrations is overlooked when using these acute lethal toxicity procedures. Additional arguments against the use of acute lethal test data for evaluating environmentally 'acceptable' concentrations have been presented by Brown (1981).

A more realistic approach to obtaining 'safe' concentrations is the determination of minimal effect levels (instead of LC 50 values). Minimal effects concentrations (MEC) are concentrations at which the first 
significant differences in the test criterion used appear, when compared to blanks. Thus MEC values depend on the criterion used, and this criterion should be a sensitive and ecologically meaningful parameter, e.g. the life-cycle events of the test species.

In this report, we study the toxicity of cadmium to 3 marine and brackish-water nematodes. We determine LC 50 values in consecutive experimental periods and compare these with MEC values based on juvenile mortality and development time.

\section{MATERIAL AND METHODS}

Test-species and food-organisms. The 3 nematode species used are bacterivorous. The cosmopolitan Monhystera disjuncta is a non-selective deposit-feeder (Gerlach \& Riemann 1973). It was isolated from the 'sluice dock' of Ostend (Belgium), a marine lagoon near the coast. $M$. microphthalma is a brackish-water bacterivorous non-selective deposit-feeder. It was isolated from the 'Dievengat', a poly-mesohaline pond, situated in a polder in northwestern Belgium. PeIlioditis marina is a euryhaline and bacterivorous species (Tietjen et al. 1970). It too was isolated from the 'Dievengat' (consult Vranken \& Heip 1983 for an agnotobiotic culture method). Adults of the 3 species have an individual wet weight of $0.5 \mu \mathrm{g}$. The total length of the juveniles used to start the experiments varied between 300 and $400 \mu \mathrm{m}$ in $M$. disjuncta and $M$. microphthalma, and between 400 and $450 \mu \mathrm{m}$ in $P$. marina. The 3 test species were grown in monoxenic bacterial cultures. An isolate (previously labeled as $\mathrm{ISC}_{2}$ ) belonging to the Alteromonas haloplanktis rRNA branch was used as food-organism. This strain possesses an exceptionally high nutritional value for all 3 nematode-species (Vranken et al. 1984). The bacterial strain was isolated from the sluice dock of Ostend. Purification was done according to the streak plate method on marine nutrient-agar. DNA-IRNA hybridization (De Ley \& De Smedt 1975) was used to identify the strain $\mathrm{ISC}_{2}$. Bacterial cultures were grown separately either on solid medium (marine nutrient agar) or liquid medium (marine heart infusion broth), thus sim- plifying the culture medium of Vranken et al. (1984). Addition of a sterol mixture (see below) turned out to be indispensable for completing the life-cycles in all 3 test-species.

Cultures. Temperature, salinity and $\mathrm{pH}$ were kept constant at favourable intensities for laboratory tests. Pellioditis marina and Monhystera disjuncta were cultivated at $17^{\circ} \mathrm{C}$ and $30 \% \mathrm{~S} ; \mathrm{M}$. microphthalma, at $25^{\circ} \mathrm{C}$ and $20 \% \mathrm{~S}$. In all tests the $\mathrm{pH}$ ranged between 7 and 7.5. The nematodes were cultured in a nutrient-poor culture-medium $(0.5 \%$ bacto-agar) in small vented Petri dishes $(\varnothing: 35 \mathrm{~mm})$ to which the bacterial food was added in a central-ring-shaped excavation in the agar (Fig. 1). This technique has several advantages:(1) Bacterial growth is limited due to the lack of nutrients, resulting in a clear and easily observable culture; (2) axenization procedures can be restricted to a minimum because the development of other bacteria (contaminants) is very limited; (3) reproducibility of the tests is greatly enhanced, and mortality during pre-adult stages is nearly zero in the control.

Food preparation. Erlenmeyer flasks $(100 \mathrm{ml})$ were filled with $50 \mathrm{ml}$ heart infusion broth suspended in artificial seawater according to Dietrich \& Kalle (1957) and then sterilized. The medium was inoculated with the bacterial strain $\left(\mathrm{ICS}_{2}-\right.$ Alteromonas haloplanktis) under a horizontal laminar air flow bench (NUAIRE201 - Table Model). The culture was incubated for $48 \mathrm{~h}$ at $20^{\circ} \mathrm{C}$ in a Heraeus-incubator and rotated in a rotary shaking machine (INFORS - AG-CH-4103) at $125 \mathrm{rpm}$. Bacterial growth was measured with a Vitatron UPMUniversal Photometer measuring the absorbance at $546 \mathrm{~nm}$. Bacterial cells were harvested by centrifugation at $6000 \mathrm{rpm}$ for $15 \mathrm{~min}$. The pellet was resuspended in sterile artifical seawater and added to the cultures.

Nematode culture medium. Small vented Petri dishes $(\varnothing 35 \mathrm{~mm}$ ) were filled with $4 \mathrm{ml} 0.5 \%$ bacto-agar (Difco) in artificial seawater to which $0.2 \mathrm{ml}$ of a sterol mixture was added (containing $10 \mu \mathrm{g} \mathrm{ml}{ }^{-1}$ each of: cholesterol, stigmasterol, ergosterol, 7-dehydrocholesterol, and $\beta$-sitosterol). After the agar cooled down, a central ring-shaped excavation $(\varnothing: 15 \mathrm{~mm})$ was made into the culture medium by pushing the top

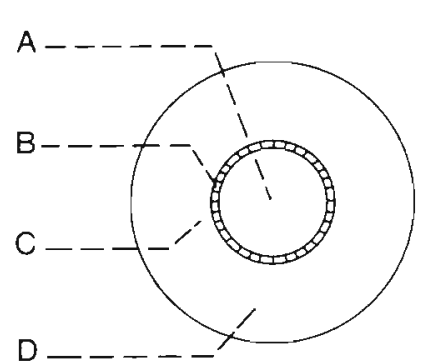

a

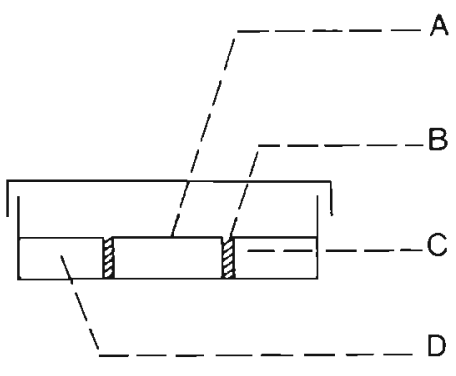

b
Fig. 1. Scheme of starting a standardized nematode culture. (a) Top view; (b) side view. A: central zone; $B$ : ring-shaped excavation where bacterial suspension is added; C: zone with lower bacterial concentrations due to agar-diffusion and bioturbation; $\mathrm{D}$ : zone in which the axenizised nematodes are inoculated 
of a sterile test tube to the bottom of the Petri dish. This excavation was then filled with $\pm 0.05 \mathrm{ml}$ of bacterial suspension.

Axenization of nematodes. With a treatment of 1000 $\mathrm{IU}$ penicillin and $1 \mathrm{mg} \mathrm{ml}^{-1}$ streptomycin during $20 \mathrm{~h}$ in $0.5 \%$ agar, all 3 test species could be axenizised satisfactorily. Monhystera microphthalma and Pellioditis marina had been successfully kept in monoxenic stock cultures for several months. In $M$. disjuncta egg mortality increased considerably when kept too long in monoxenic cultures; hence stock cultures of $M$. disjuncta were kept under agnotobiotic conditions, and axenization became necessary for starting monoxenic tests.

Toxicity tests. A stock solution of $1000 \mathrm{ppm} \mathrm{Cd}^{2+}$ was prepared in artificial seawater using $\mathrm{CdCl}_{2}$. $2 \frac{1}{2} \mathrm{H}_{2} \mathrm{O}$, and diluted to final concentrations of $1,2.5$, 7.5, 10 and $25 \mathrm{ppm} \mathrm{Cd}^{2+}$ for Monhystera microphthalma; $1,5,10$ and $25 \mathrm{ppm} \mathrm{Cd}^{2+}$ for $M$. disjuncta; 1,5 , $10,25,50,60,70,80$ and $100 \mathrm{ppm} \mathrm{Cd}^{2+}$ for Pellioditis marina. Monospecific bacterial cells $\left(\mathrm{ISC}_{2}\right)$ were grown at the same $\mathrm{Cd}$ concentrations as the tests, before they were added to the cultures. Acute $\mathrm{Cd}$ toxicity to this bacterial strain occurred between 25 and $50 \mathrm{ppm}$, so that toxicity tests above $25 \mathrm{ppm} \mathrm{Cd}$ were carried out using bacterial cells grown at $25 \mathrm{ppm}$ Cd. Test organisms were first grown monoxenically on a diet of metal-free cells of Alteromonas haloplanktis until the age of $2.5 \mathrm{~d}$ ( $P$. marina), $5.5 \mathrm{~d}$ ( $M$. microphthalma) or $4.5 \mathrm{~d}$ (M. disjuncta). At this age juveniles were transferred to the different $\mathrm{Cd}$ concentrations.
Each concentration consisted of 4 replicates in which ca 110 nematodes were tested. For $P$. marina the control consisted of 8 replicates containing a total of 229 individuals. For $M$. disjuncta we used ca 60 individuals per concentration; the control consisted of 5 replicates (93 nematodes); from these, 4 replicates were monitored daily to estimate mean development time. For $M$. microphthalma the control consisted of 2 separate experimental sets, with 4 replicates each; 1 set was used to determine development time. For $M$. microphthalma the control consisted of 2 separate experimental sets, with 4 replicates each; 1 set was used to determine development time. Observations on mortality were made once daily. Criteria for death were inactivity and failure to respond after stimulation with a needle.

\section{RESULTS}

\section{LC 50 and MEC}

Homogeneity of mortality rates obtained in the different $\mathrm{Cd}$ concentrations was investigated by $\mathrm{G}_{\mathrm{H}}$-statistic (Sokal \& Rohlf 1981), computed for final mortalityresponse. In only 2 of the 21 series conducted ( 2.5 and 7.5 ppm Cd, Monhystera microphthalma) did heterogeneous responses occur in the different replicates $(0.001<\mathrm{P}<0.01)$. This may have been the result of uncontrolled pH-fluctuations. In later experiments Tris buffer $(0.5 \mathrm{mM})$ was used to compensate for similar difficulties.

Table 1. Minimal effect concentrations (MEC-values) and LC 50 values of nematodes for $\mathrm{Cd}^{2+}$, obtained over different incubation periods. Values in brackets following MEC values: mortalities in percentages. MEC values were computed at the $P=0.05$ level with the G-test (Sokal \& Rohlf, 1981); $95 \%$ confidence limits around LC 50 calculated according to Sokal \& Rohlf (1981); b and $\mathrm{r}^{2}$ :

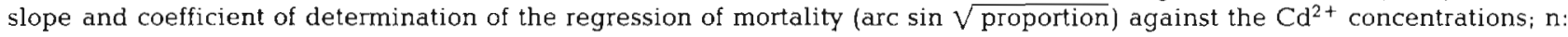
number of points used in the regression

\begin{tabular}{|c|c|c|c|c|c|c|c|c|}
\hline Species & $\begin{array}{l}\text { Exposure } \\
\text { time } \\
\text { (h) }\end{array}$ & $\mathrm{G} / \mathrm{q}$ & $\begin{array}{l}\mathrm{MEC} \\
(\mathrm{ppm} \\
\left.\mathrm{Cd}^{2+}\right)\end{array}$ & $\begin{array}{l}\mathrm{LC} 50 \\
(\mathrm{ppm} \\
\left.\mathrm{Cd}^{2+}\right)\end{array}$ & $\begin{array}{c}95 \% \mathrm{CI} \\
(\mathrm{ppm} \\
\left.\mathrm{Cd}^{2+}\right)\end{array}$ & $\mathrm{b}( \pm \mathrm{SE})$ & $\mathrm{r}^{2}$ & $\mathrm{n}$ \\
\hline \multirow[t]{5}{*}{ M. microphthalma } & 72 & $101 \cdots$ & $25(24)$ & - & - & - & - & - \\
\hline & 96 & $224^{\cdots}$ & $7.5(8)$ & 24 & $20.6-26.6$ & $1.93( \pm 0.112)$ & 0.93 & 24 \\
\hline & 144 & $495^{\cdots}$ & $7.5(26)$ & 13 & $10.4-15.1$ & $3.28( \pm 0.190)$ & 0.93 & 24 \\
\hline & 240 & $663 \cdots$ & 1 (6) & 6 & $4.4-8.1$ & $6.79( \pm 0.663)$ & 0.85 & 20 \\
\hline & 312 & $757^{\cdots} \cdots$ & $1(6)$ & 5 & $4.2-6.8$ & $8.03( \pm 0.550)$ & 0.92 & 20 \\
\hline \multirow[t]{4}{*}{ M. disjuncta } & 96 & $57^{\cdots} \cdots$ & $25(22)$ & - & - & - & - & - \\
\hline & 144 & $110^{\cdots}$ & $10(10)$ & - & - & - & - & - \\
\hline & 192 & $199^{\cdots} \cdots$ & $10(15)$ & 21 & $17.0-26.2$ & $2.53( \pm 0.247)$ & 0.91 & 12 \\
\hline & 264 & $253^{\cdots}$ & $10(26)$ & 18 & $13.9-23.5$ & $2.83( \pm 0.299)$ & 0.90 & 12 \\
\hline \multirow[t]{4}{*}{ P. marina } & 72 & $43 \cdots$ & $60(4)$ & - & - & - & - & - \\
\hline & 96 & $171 \cdots$ & $50(9)$ & - & - & - & - & - \\
\hline & 120 & $388^{\cdots}$ & $50(14)$ & 91 & $76.0-109.0$ & $0.74( \pm 0.095)$ & 0.73 & 24 \\
\hline & 192 & $609^{\cdots}$ & 50 (14) & 77 & $66.6-88.4$ & $1.02( \pm 0.096)$ & 0.84 & 24 \\
\hline
\end{tabular}



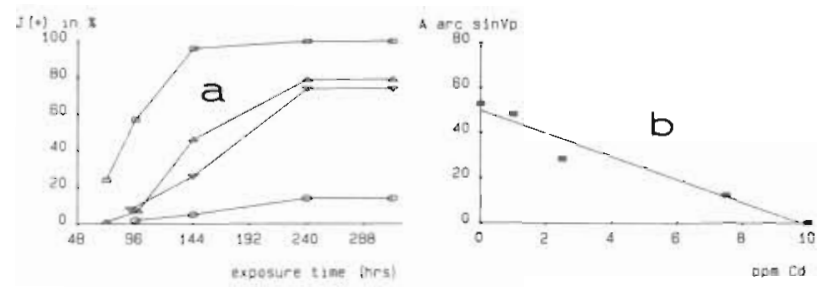

Fig. 2. Monhystera microphthalma. (a) Cumulative mortality $(\%)$ for different Cd concentrations: $2.5 \mathrm{ppm}(\mathrm{O}) ; 7.5 \mathrm{ppm}(\nabla)_{i}$ $10 \mathrm{ppm}(\triangle) ; 25 \mathrm{ppm}(\square)$, at different exposure times (h). (b) Number of adults $(\%)$ after $72 \mathrm{~h}(=$ time period within which ca $50 \%$ of the nematodes reached adulthood in the control)

For Monhystera microphthalma Fig. 2a shows the percentage mortality at the 4 highest $\mathrm{Cd}$ concentrations at 5 different observation times. Table 1 gives the G/q statistics (Sokal \& Rohlf 1981), which test whether juvenile mortality is significantly influenced by the concentrations applied. These calculations demonstrate that at each observation time there exists a pronounced influence of $\mathrm{Cd}(\mathrm{P}<0.001)$. The minimal effect concentration (MEC values in Table 1) declines sharply from $25 \mathrm{ppm} \mathrm{Cd}$ after $72 \mathrm{~h}$ to $1 \mathrm{ppm} \mathrm{Cd}$ after $240 \mathrm{~h}$ exposure. At $25 \mathrm{ppm} \mathrm{Cd}$, the highest $\mathrm{Cd}$ level tested for $M$. microphthalma mortality increased from $24 \%$ after $72 \mathrm{~h}$ to $100 \%$ after $240 \mathrm{~h}$, whereas at the smallest concentration ( $1 \mathrm{ppm} \mathrm{Cd}$ ) mortality varied between $0 \%$ after $72 \mathrm{~h}$ and $6 \%$ after $312 \mathrm{~h}$.

LC 50 values were calculated for each exposure time by inverse prediction from the regression of mortality, transformed into angles (arc sin $\sqrt{\mathrm{p}}$ transformation) against $\mathrm{Cd}$ concentration. The slopes of these regressions with their standard errors (SE) are shown in Table 1. For Monhystera microphthalma the regressions for the different incubation times are highly sig-
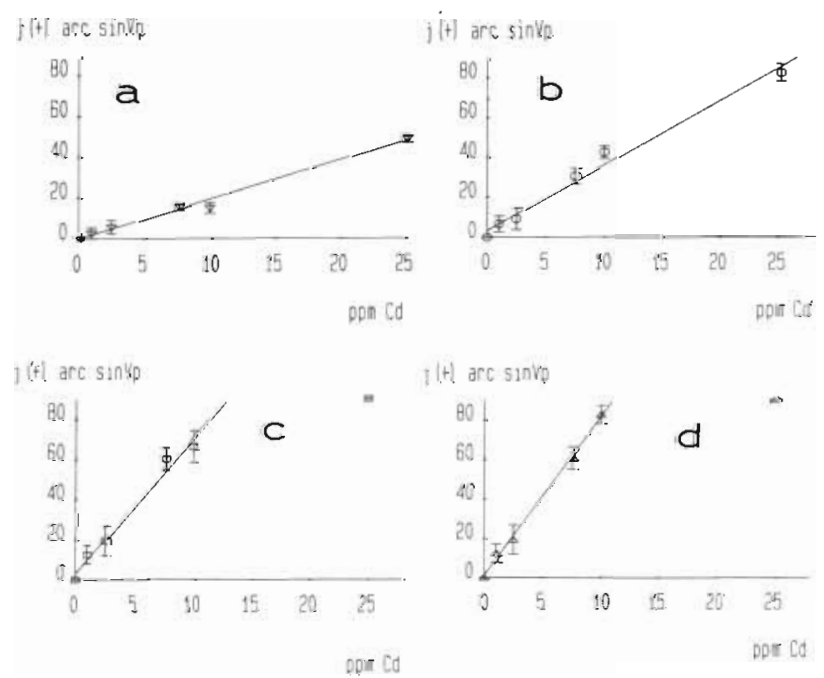

Fig. 3. Monhystera microphthalma. Juvenile mortality after $96 \mathrm{~h}$ (a); $144 \mathrm{~h}$ (b); $240 \mathrm{~h}$ (c); $312 \mathrm{~h}$ (d). Bars: standard errors of 4 simultaneous experiments nificant $(P<0.001)$ (Fig. 3) with coefficients of determination $\left(\mathrm{r}^{2}\right)$ ranging between $0.93(144 \mathrm{~h})$ and 0.85 $(240 \mathrm{~h})$. LC 50 values decrease from $23.6 \mathrm{ppm}$ Cd after $96 \mathrm{~h}$ to $6.2 \mathrm{ppm} \mathrm{Cd}$ after $240 \mathrm{~h}$. A further but less substantial decrease of LC 50 was observed as incubation time increased from $240 \mathrm{~h}$ to $312 \mathrm{~h}$. The values of the slopes ( $b$ in Table 1) may be considered a measure of sensitivity of the test-organism to the range of the toxicant. High b's indicate high and fast mortalities; small b's, insensitivity accompanied with small mortalities. For $M$. microphthalma b values increase from 1.93 after $96 \mathrm{~h}$ to 8.03 after $312 \mathrm{~h}$. However $\mathrm{b}$ values are not independent from each other since they were calculated from the same experimental set. Therefore $b$ values obtained for different exposure times cannot be compared statisticaliy. Nievertheless, a 4 -fold increase of $\mathrm{b}$ is noted with $M$. microphthalma. This shows clearly that $\mathrm{Cd}$ toxicity is highly dependent on exposure time (Fig. 3). LC 50 obtained after $96 \mathrm{~h}$ dramatically underestimates the toxicity of this particular metal.

Table 1 also shows the results obtained with the other test species. For Monhystera disjuncta a highly significant influence of $\mathrm{Cd}(\mathrm{P}<0.001)$ was noted after each observation time. MEC after $96 \mathrm{~h}$ was $25 \mathrm{ppm} \mathrm{Cd}$; at this concentration $22 \%$ of the juveniles died after 96 h (Fig. 4 c). After $264 \mathrm{~h}$ mortality at this concentration increased to $77 \%$ (Fig. $4 \mathrm{c}$ ). At the other 3 observation times $\mathrm{MEC}$ remained at $10 \mathrm{ppm} \mathrm{Cd}$. At $10 \mathrm{ppm} \mathrm{Cd}$, mortality rose from $2 \%$ after $96 \mathrm{~h}$, a value not different from the blank, to $26 \%$ after $264 \mathrm{~h}$ (Fig. 4 c). LC 50 values for $M$. disjuncta were $21.2 \mathrm{ppm}$ after $192 \mathrm{~h}$, and $18.4 \mathrm{ppm}$ after $264 \mathrm{~h}$. The data set obtained after $144 \mathrm{~h}$ does not encompass the LC 50.
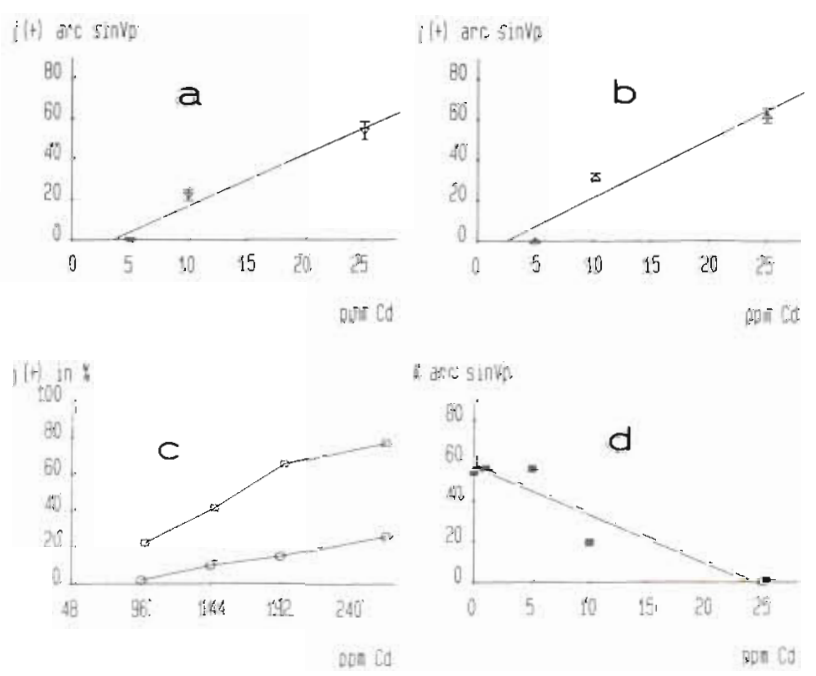

Fig. 4. Monhystera disjuncta. (a) Juvenile mortality after 192 h. (b) Juvenile mortality after 264 h. Bars: standard errors of 4 simultaneous replicates. (c) Cumulative mortality (\%) for different $\mathrm{Cd}$ concentrations: $10 \mathrm{ppm}(\mathrm{O}) ; 25 \mathrm{ppm}(\square)$, at different exposure times (h). (d) Number of adults (\%) after $120 \mathrm{~h}$ 


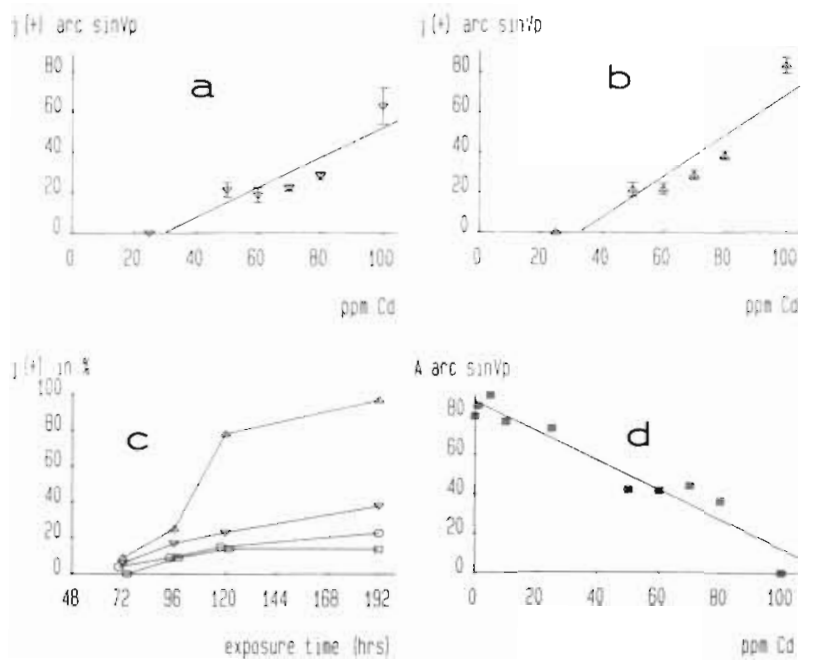

Fig. 5. Pellioditis marina. (a) Juvenile mortality after 120 h. (b) Juvenile mortality after $192 \mathrm{~h}_{\text {i }}$ intervals in (a) and (b): standard errors of 4 replicates. (c) Cumulative mortaility (\%) for different Cd concentrations: $50 \mathrm{ppm}(\square) ; 70 \mathrm{ppm}(\mathrm{O}) ; 80 \mathrm{ppm}$ $(\nabla) ; 100 \mathrm{ppm}(\Delta)$, at different exposure times (h). (d) Number of adults (\%) after $72 \mathrm{~h}$

For Pellioditis marina (Fig. 5c), mortality was $8 \%$ at 100 ppm Cd after $72 \mathrm{~h}$ and $97 \%$ at 100 ppm after $192 \mathrm{~h}$. After 72 and $96 \mathrm{~h}$ we could not estimate the LC 50. LC 50 values after 120 and $192 \mathrm{~h}$ were 90.5 and $77 \mathrm{ppm} \mathrm{Cd}$. Again, there is obvious increase in sensitivity as indicated by the b value (Fig. $5 \mathrm{a}$, b) which increased from 0.74 after $120 \mathrm{~h}$ to 1.02 after $192 \mathrm{~h}$. MEC was $60 \mathrm{ppm} \mathrm{Cd}$ after $72 \mathrm{~h}$, and $50 \mathrm{ppm}$ for the other periods (Table 1).

\section{Development to adulthood}

A developmental assay (Table 2), in which the percentages of individuals attaining the adult stage are compared with the control, was obtained at the time when at least $50 \%$ of the individuals reached the adult stage in the blank. In Monhystera microphthalma and

Table 2. Minimal effect $C d$ concentrations at the $P=0.05$ level (G-test) obtained from a developmental assay of nematodes in which the successfulness of attaining the adult stage is compared with the blank. Values in brackets: percentage of adult individuals ( $q$ and $\delta$ ) obtained after the exposure time indicated

\begin{tabular}{|lrrrrr|}
\hline \multicolumn{1}{|c}{ Species } & $\begin{array}{c}\text { Exposure } \\
\text { time } \\
(\mathrm{h})\end{array}$ & $\mathrm{G} / \mathrm{q}$ & $\begin{array}{c}\mathrm{MEC} \\
\left(\mathrm{ppm} \mathrm{Cd} \mathrm{Cd}^{2+}\right)\end{array}$ & $\begin{array}{c}\text { Con- } \\
\text { trol }\end{array}$ \\
\hline M. microphthalma & 72 & $346 \cdots$ & $2.5(23)$ & $(63)$ \\
M. disjuncta & 120 & $194 \cdots$ & $10(11)$ & $(67)$ \\
P. marina & 72 & $725 \cdots$ & $50(45)$ & $(97)$ \\
$\cdots \mathrm{P}<0.001$ & & & & \\
\hline
\end{tabular}

Pellioditis marina this percentage was monitored ca $72 \mathrm{~h}$ after initiation; in $M$. disjuncta it took $120 \mathrm{~h}$ before $67 \%$ of the $4.5 \mathrm{~d}$ old juveniles reached adulthood in the blank. MEC obtained in this assay are listed in Table 2. For all 3 species, the decline in the percentages of individuals attaining adulthood $(\mathrm{A})$ is a linear function of $\mathrm{Cd}$ concentration (C).

This can be described by the following equations: M. microphthalma:

$$
\begin{aligned}
& A=49.74-5.09 C\left(r^{2}=0.95 ; n=5\right) \\
& \text { (Fig. 2b) (1) } \\
& \text { M. disjuncta: } \quad \mathrm{A}=57.06-2.41 \mathrm{C}\left(\mathrm{r}^{2}=0.88 ; \mathrm{n}=5\right) \\
& \text { (Fig. 4d) (2) } \\
& \text { P. marina: } \quad \mathrm{A}=86.89-0.75 \mathrm{C}\left(\mathrm{r}^{2}=0.93 ; \mathrm{n}=10\right) \\
& \text { (Fig. 5d) (3) }
\end{aligned}
$$

\section{Development times}

Table 3 compiles mean development times (pooled sexes) for different Cd levels. While in Monhystera disjuncta and Pellioditis marina only the higher concentrations caused a prolongation of development time, in $M$. microphthalma even the lowest concentration (1 ppm) led to a significant increase in the developmental period $\left(\mathrm{T}_{\min }\right)$.

Table 3. Development time $\left(\mathrm{T}_{\mathrm{mn}}\right)$ of pooled sexes in nematodes, with $95 \%$ confidence interval (CI) in parentheses

\begin{tabular}{|c|c|c|c|}
\hline Species & $\begin{array}{l}\mathrm{Cd}^{2+} \\
(\text { ppm })\end{array}$ & $\mathrm{T}_{\min }( \pm \mathrm{CI})$ & $N$ \\
\hline \multirow[t]{6}{*}{ M. microphthalma } & Control & $8.9( \pm 0.20)$ & 113 \\
\hline & 1 & $9.6( \pm 0.35)$ & 98 \\
\hline & 2.5 & $9.6( \pm 0.28)$ & 86 \\
\hline & 7.5 & $9.7( \pm 0.35)$ & 26 \\
\hline & 10 & $14.5( \pm 11.37)$ & 3 \\
\hline & 25 & - & - \\
\hline \multirow[t]{5}{*}{ M. disjuncta } & Control & $9.6( \pm 0.25)$ & 61 \\
\hline & 1 & $9.4( \pm 0.24)$ & 67 \\
\hline & 5 & $9.4( \pm 0.25)$ & 59 \\
\hline & 10 & $11.7( \pm 0.72)$ & 27 \\
\hline & 25 & - & - \\
\hline \multirow[t]{10}{*}{ P. marina } & Control & $5.2( \pm 0.07)$ & 229 \\
\hline & 1 & $4.9( \pm 0.09)$ & 116 \\
\hline & 5 & $5.0( \pm 0.09)$ & 114 \\
\hline & 10 & $5.0( \pm 0.11)$ & 112 \\
\hline & 25 & $5.6( \pm 0.05)$ & 107 \\
\hline & 50 & $6.4( \pm 0.24)$ & 88 \\
\hline & 60 & $6.0( \pm 0.12)$ & 94 \\
\hline & 70 & $6.0( \pm 0.16)$ & 80 \\
\hline & 80 & $6.0( \pm 0.16)$ & 64 \\
\hline & 100 & $7.2( \pm 1.40)$ & 3 \\
\hline
\end{tabular}
at different $\mathrm{Cd}^{2+}$ concentrations (ppm). N: number of adults ( $q$ and $\delta$ pooled). Experiments were started with $5.5 \mathrm{~d}$ old juveniles of Monhystera microphthalma, $4.5 \mathrm{~d}$ old juveniles of M. disjuncta, and $2.5 \mathrm{~d}$ old Pellioditis marina. Time zero: moment of egg-deposition 


\section{DISCUSSION}

\section{Sensitivity to heavy metals}

The experimental procedure described in this study is completely new, very simple to work with, and results in homogeneous responses both in regard to mortality rates and development time. Our results document that the 3 nematode species tested exhibit large differences in tolerance to cadmium exposure. They all are relatively insensitive to $\mathrm{Cd}$ intoxication, hence high Cd levels are required to induce a $50 \%$ death rate. Using 192 h LC 50 as criterion, Monhystera microphthalma can be classified as the most sensitive species; it is 2 times more susceptible to $\mathrm{Cd}$ than $M$. disjuncta: and 8 times more sensitive than Pellioditis marina. Acute lethal toxicity levels (LC 50) for the latter species are $90 \mathrm{ppm} \mathrm{Cd}$ after $120 \mathrm{~h}$ and $77 \mathrm{ppm} \mathrm{Cd}$ after $192 \mathrm{~h}$. Similarly high LC 50 values have been recorded for other nematodes: LC 50 for the second juvenile stage (J2) of Panagrellus silusiae varied between $36 \mathrm{ppm} \mathrm{Cd} \mathrm{(24} \mathrm{h)} \mathrm{and} 5.85$ ppm (72 h) (Haight et al. 1982); Feldmesser \& Rebois (1966) report $48 \mathrm{~h} \mathrm{LC}$ 50 between 35 and 40 ppm for mixed populations of Panagrellus and Rhabditis; Samoiloff et al. (1980) found no decrease in survival rates of $P$. redivivus at $1.12 \mathrm{ppm}$, the lowest concentration causing a significant reduction in survival was $11.2 \mathrm{ppm} \mathrm{Cd}$.

Several marine organisms exhibit similarly high resistance levels to $\mathrm{Cd}$ intoxication: in fiddler crabs Uca pugilator acute toxicity levels ranged from ca 10 ppm $(240 \mathrm{~h})$ to $50 \mathrm{ppm}(96 \mathrm{~h})$ (O'Hara 1973, cited in Bryan 1976). The harpacticoid copepod Nitocra spinipes (Bengtsson 1978) exhibits intermediate sensitivities with an $96 \mathrm{~h}$ LC 50 of $1.8 \mathrm{ppm} \mathrm{Cd}$. The hydroids Laomedea loveni (Theede et al. 1979) and Eirene viridula (Karbe 1972) are particularly sensitive to Cd exposures; their LC 50 values range from 3 to 80 ppb (168 h), and from 100 to $300 \mathrm{ppb}$ Cd, respectively ('akute Schadwirkungen'). The freshwater Daphnia magna is also very sensitive compared with the nematodes; it has a $48 \mathrm{~h} \mathrm{LC} 50$ of $65 \mathrm{ppb}$ Cd (Biesinger \& Christensen 1972). The brine shrimp Artemia sp. has a $168 \mathrm{~h}$ LC 50 of $50 \mathrm{ppm} \mathrm{Cd}$ (Brown \& Ashanullah 1971).

These examples indicate considerable differences between taxa. Such differences may result from differences in permeability, uptake mechanisms, and/or rates of Cd accumulation (George \& Coombs 1977, Coombs \& George 1978, George et al. 1978). They may also be attributed to the presence or absence of $\mathrm{Cd}$ binding proteins (metallothioneins) that possess a $\mathrm{Cd}$ detoxication and immobilization function (Olafson \& Thompson 1974, Lee et al. 1977), or to the capacity for storing metals in granules and vesicles, thus sequester- ing the metal, and hence eliminating or at least reducing the toxic impact of the metal (Coombs \& George 1978).

It has been reported repeatedly that $\mathrm{Cd}$ toxicity drops with increasing salinity (see Borgmann 1983 for a review). Such reduction of $\mathrm{Cd}$ toxicity at higher salinities has been attributed to increased complexation and increased competition with calcium and/or magnesium (Borgmann 1983). Phillips (1976) and George et al. (1978), working with the mussel Mytilus edulis, found a decrease in Cd uptake as salinity increases. Therefore, a certain amount of the differences in Cd tolerance reported here between the 3 nematode species may have been induced by differences in culture conditions: Monhystera microphthalma was kept at $20 \% \mathrm{~S}$, the other 2 species at $30 \% \mathrm{~S}$

The medium we used is relatively poor in nutrients and composed of bacto-agar (a highly purified agar), enriched with a mixture of 5 sterols. The agar might selectively bind metals and hence reduce their toxicity. Concerning the complexation of $\mathrm{Cd}$ by sterols, no information was found in the literature. Ramamoorthy \& Kushner (1975) reported that in comparison with $\mathrm{Hg}^{2+}, \mathrm{Pb}^{2+}$ and $\mathrm{Cu}^{2+}$, very little $\mathrm{Cd}^{2+}$ is bound by microbial growth media. Casamino-acids, not used in our medium, were the most active binding substances. In fresh water, the free cadmium ion $\mathrm{Cd}^{2+}$ is the dominant Cd form (Gardiner 1974, Bryan 1984), whereas at 20 and $30 \%$ (as in our experiments) $\mathrm{Cd}$ is almost completely complexed and present in the form of chloride complexes (Sunda et al. 1978). As Cd toxicity is a function of free $\mathrm{Cd}$ ion concentration (Sunda et al. 1978, Bryan 1984), the low Cd toxicity to the species we studied, especially in comparison with freshwater species, is comprehensible. Presumably, chloride complexation is more important in our medium than organic complexation.

\section{Field observations}

A high resistance of nematodes to environmental stress, especially due to heavy metals, is known from the field; in some polluted areas nematodes are the major survivors (Van Damme \& Heip 1977). Among the nematodes, especially the non-selective deposit feeders (to which the 3 tested species belong) are extremely pollution resistant. In the Southern Bight of the North Sea, a complete compositional shift within the nematode community has been observed from 'healthy' stations, possessing a diverse nematode community composed of all feeding types, to pollution stressed 'diseased' environments, inhabited by a 'poor' nematode community composed almost completely of 
non-selective deposit feeders. Such structural impoverishment has been correlated with heavy metal pollution (Heip et al. 1984). These observations corroborate the acute toxicity levels reported in this paper; therefore, the high LC 50 values observed in our assays are not artefacts due to the optimal culture conditions employed.

\section{Effects of exposure tíme}

We can draw 2 additional important conclusions : (1) 96 h LC 50 values dramatically underestimate the toxicity of $\mathrm{Cd}$; (2) LC 50 values are very time-dependent. In Monhystera microphthalma we found a 4-fold reduction of LC 50 by extending the exposure time from $96 \mathrm{~h}$ to $312 \mathrm{~h}$. In $M$. disjuncta and Pellioditis marina, $96 \mathrm{~h}$ LC 50 values were not determinable; in the first-named species LC 50 values were reduced from $28 \mathrm{ppm}$ at $144 \mathrm{~h}$ to $18.4 \mathrm{ppm}$ at $264 \mathrm{~h}$. A similar time-dependency of LC 50 has been reported in the literature. For the nematode Panagrellus silusiae $\mathrm{Cd}$ LC 50 was reduced from $111 \mathrm{ppm}$ after $24 \mathrm{~h}$, to 13.2 ppm for an exposure time of $72 \mathrm{~h}$ (Haight et al. 1982); LC 50 for the grass shrimp Palaemonetes vulgaris was reduced from $760 \mathrm{ppb}$ to $120 \mathrm{ppb} \mathrm{Cd}$ by extending the exposure time from $96 \mathrm{~h}$ to $29 \mathrm{~d}$ (Nimmo et al. 1977), and Best \& Morita (1983) reported that for the asexual planarian Dugesia dorotocephala the $5 \mathrm{~d}$ LC 50 was in the 2 to 3 ppm range; the $12 \mathrm{~d}$ LC 50 , less than $0.4 \mathrm{ppm}$ $\mathrm{Cd}$

\section{Possible effects of starvation}

As exposure time increases, death caused by $\mathrm{Cd}$ induced starvation has to be considered. In the course of our experiments, the intestines of well-fed juveniles of both Pellioditis marina and Monhystera disjuncta changed colour. Initially, the intestine was darkly coloured; after some time it turned very pale with a typical spotted pattern. These changes were less obvious in M. microphthalma. This indicates to us that some individuals stop, or at least reduce, their food uptake. Hence, some deaths may have been caused by starvation. Mudry et al. (1982) made analogous observations on Panagrellus silusiae; some individuals (numbers decreasing with experimental time) continue to feed in the presence of heavy metals, whereas in most of them pharyngeal pumping was completely suppressed, resulting in inactivation of normal feeding. Mudry et al. (1982) considered the cuticle as a barrier preventing the passage of heavy metals. However, Lopez et al. (1979) calculated that pumping rates in the brackish water nematode Adoncholaimus thalassophygas were too low to explain the observed uptake of ${ }^{14} \mathrm{C}$-glucose and they proposed cuticular absorption as a possible mechanism for the uptake of dissolved matter. Other studies (Samoiloff 1973, Howell 1983) indicate that the nematode cuticle is highly active. The outer part (outer cortical layer) of the 3 layered nematode body wall consists of secreted nematode collagen (Bird 1971, Lee \& Atkinson 1976) containing disulphide and sulphydryl groups which provide binding possibilities for heavy metals (Howell 1983). Consequently, this structure may play a role in the uptake of heavy metals. Furthermore Mudry et al. (1982) used only very high metal levels ( $\mathrm{Cd}=100 \mathrm{mg}$ $\left.l^{-1}\right\}_{i}$ hence it remains uncertain whether the same 'allor-none' feeding behaviour exists at lower heavymetal levels. At present, no information is available on whether this starvation behaviour depends on some threshold level.

\section{Effects of cadmium on bacterial food}

The nematodes were fed bacteria previously grown in different $\mathrm{Cd}$ concentrations. Growth inhibition of the bacterium occurred between 20 and $50 \mathrm{ppm} \mathrm{Cd}$. Similar results have been obtained by Doyle et al. (1975) who studied the influence of Cd on 6 microorganisms commonly found in the intestinal tract of man. Two species, Escherichia coli and Bacillus cereus, grew well at 40 and $80 \mu \mathrm{g} \mathrm{Cd} \mathrm{ml}^{-1}$, whereas the growth of the other species was depressed. Alteromonas haloplanktis, the food organism used in our experiments, is a Gram-negative bacterium and in comparison with Gram-positive bacteria, appears to be more resistant (Babich \& Stotzky 1977, Jakubczak et al. 1981). High resistance with the Gram-positive bacterium Staphylococcus aureus is plasmid mediated (Novick \& Roth 1968). The penicillinase phasmids carried separate loci for resistance to inorganic ions, among them cadmium. Such resistant plasmid-carrying cells possess a mechanism for preventing $\mathrm{Cd}$ uptake (Summers \& Silver 1978). For example, in $E$. coli which shows a similar $\mathrm{Cd}$ resistance to that of $A$. haloplanktis, $\mathrm{Cd}$ uptake is very low (Doyle et al. 1975, Mitra et al. 1975). Consequently, Cd passage to bacterial feeders may be limited. In contrast, Patrick \& Loutit (1976) reported that bacteria were able to concentrate $\mathrm{Cr}, \mathrm{Cu}, \mathrm{Mn}, \mathrm{Fe}$, $\mathrm{Pb}$ and $\mathrm{Zn}$ ( $\mathrm{Cd}$ was not studied) from sediment and an artifical growth medium, and that tubificids - when fed bacteria containing metals - showed increased metal concentrations. Similar results have been obtained by Berk \& Colwell (1981) who studied the transfer of mercury through a marine microbial food web. The 2 bacterial species used, Vibrio sp. and Pseudomonas 
sp., accumulated considerable amounts of mercury. A magnification factor of more than 250 times has been observed with Pseudomonas sp. Ciliates feeding on the bacteria accumulated the mercury, whereas copepods fed labelled ciliates contained less mercury than the ciliates. As the toxicity and the uptake of cadmium is highly differential among the bacterial species studied (Doyle et al. 1975, Babich \& Stotzky 1977), it is rather difficult to speculate upon $\mathrm{Cd}$ accumulation by $A$. haloplanktis. Nevertheless, it is clear that microorganisms accumulate $\mathrm{Cd}$ and hence pass it to higher trophic levels.

\section{What are toxic levels?}

We observed no developmental inhibition in Pellioditis marina and Monhystera disjuncta in the 0 to 10 ppm Cd range; higher Cd levels caused only small increases in development time. In M. microphthalma, a different response was observed; compared to the blank, all test concentrations caused a slight developmental retardation. The degree of inhibition is too low to assume large chances in food uptake.

Besides starvation and high resistance, Popham \& Webster (1979) reported several structural changes of Cd exposed nematodes Caenorhabditis elegans. Using electron microscopy, they observed modifications of mitochondria in intestine and oesophagus, disrupted cytosomes, shorter microvilli of the intestinal cells, and the formation of nuclear inclusions in the oesophageal cells. Such modifications preclude death.

The inappropriateness of death as a criterion for determining environmentally safe concentrations is well known (e.g. Samoiloff et al. 1980). Only at 11.2 ppm $\mathrm{Cd}$ did these authors observe a significantly decreased survival, compared to the control. Using fecundity as a criterion, Samoiloff (1980) observed a significant reduction at as little as $11.2 \mathrm{ppb}$. According to Reish \& Carr (1978) reproductive suppression in 2 polychaetes (Ctenodrilus serratus, Ophryotrocha diadema) was 2 orders of magnitude less than the $96 \mathrm{~h}$ LC 50. Death is too slow and too rough a criterion.

While LC 50 tests remain a useful and quick criterion for toxicity testing and for the effect ranking of chemical agents, these tests are not sensitive enough to determine minimum effective concentrations, i.e. concentrations inducing detrimental effect, not present in healthy individuals and leading to health impairment (Reish \& Carr 1978). A compromise is to use death as a rough ranking criterion, but to consider the lowest concentration which induces a negative response significantly different from the control as a concentration intolerable to the environment. For the 3 nematode species tested by us these MEC concentrations are very high.

\section{Other tests}

For a short-term test with higher sensitivity than the traditional LC 50 test we developed an assay in which we monitored the number of adults at the time when ca $50 \%$ of the nematodes reached adulthood in the control. These numbers represent 2 different responsetypes: mortality and developmental inhibition. The MEC values obtained from such experimental design are very similar to those recorded in mortality experiments, but this test takes considerably less time. Another promising feature is that the response curves of the 3 species show basically the same pattern. Hence, comparison of the slopes obtained for different species may yield additional information on the species' sensitivity to pollutant stress. Further investigations with other metals and other nematode species are necessary to corroborate the present findings.

Acknowledgements. This research was conducted under contract No. ENV. 566 B of the Environmental Programme of the CEC, and supported through the Concerted Actions Oceanography Project of the Ministry of Scientific Policy. C. Heip acknowledges a grant of the Belgian National Science Founation (NFWO). The authors thank Mr. B. Pot and Dr. M. Gillis for determination of the bacterial strain $\mathrm{ISC}_{2}$

\section{LITERATURE CITED}

Ahsanullah, M., Negilski, D. S., Mobley, M. C. (1981). Toxicity of zinc, cadmium and copper to the shrimp Callianassa australiensis. I. Effects of individual metals. Mar. Biol. 64: 299-304

Babich, H., Stotzky, G. (1977). Sensitivity of various bacteria, including actinomycetes, and fungi to cadmium and the influence of $\mathrm{pH}$ on sensitivity. Appl. environ. Microbiol. 33: $681-695$

Bengtsson, B. E. (1978). Use of a harpacticoid copepod in toxicity tests. Mar. Pollut. Bull. 9: 238-241

Berk, S. G., Colwell, R. R. (1981). Transfer of mercury through a marine microbial food web. J. exp. mar. Biol. Ecol. 52: $157-172$

Best, J. B., Morita, M. (1983). Toxic responses of planarians to various waterborne heavy metals. In: Niagru, J. O. (ed.) Aquatic toxicology. John Wiley and Sons, New York, p. $137-154$

Biesinger, K. E., Christensen, G. M. (1972). Effects of various metals on survival, growth, reproduction and metabolism of Daphnia magna. J. Fish. Res. Bd Can. 29: 1691-1700

Bird, A. F. (1971): The structure of nematodes. Academic Press, New York, London

Borgmann, U. (1983). Metal speciation and toxicity of free metal ions to aquatic biota. In: Niagru, J. O. (ed.) Aquatic toxicology. John Wiley and Sons, New York, p. 47-72

Brown, V. M. (1981). The analysis and interpretation of acute toxicity tests data. In: Leclerc, H., Dive, D. (ed.) Acute aquatic ecotoxicological tests. Methodology-Standardization-Significance. Inserm, Paris, p. 475-484

Brown, B., Ahsanullah, M. (1971). Effect of heavy metals on mortality and growth. Mar. Pollut. Bull. 2: 182-186

Bryan, G. W. (1976). Heavy metal contamination in the sea. 
In: Johnston, R. (ed.) Marine pollution. Academic Press, London, p. 185-302

Bryan, G. W. (1984). Pollution due to heavy metals and their compounds. In: Kinne, O. (ed.) Marine ecology, Vol. V, Ocean management, Part 3. Wiley, Chichester, p. $1289-1431$

Coombs, T. L., George, S. G. (1978). Mechanisms of immobilization and detoxication of metals in marine organisms. In: McLusky, D. S., Berry, A. J. (ed.) Physiology and behaviour of marine organisms. Proceedings of the 12th European Marine Biology Symposium. Pergamon Press, Oxford, p. 179-187

De Ley, J., De Smedt, J. (1975). Improvements of the membrane filter method for DNA: rNA hybridizations. Antonie van Leeuwenhoek. J. Microb. Serol. 41: 287-307

Dietrich, G., Kalle, K. (1957), Allgemeine Meereskunde. Eine Einführung in die Ozeanographie. Gebrüder Borntraeger, Berlin-Nikolassee

Doyle, J. J., Marshall, R. T., Pfander, W. H. (1975). Effects of cadmium on the growth and uptake of cadmium by microorganisms. Appl. Microbiol. 29: 562-564

Feldmesser, J., Rebois, R. V. (1966) Nematocidal effects of several cadnium compounds. Nematologica 12: 91

Gardiner, J. (1974). The chemistry of cadmium in natural water. I. A study of cadmium complex formation using the cadmium specific-ion electrode. Wat. Res. 8: 23-30

George, S. G., Carpene, E., Coombs, T. L. (1978). The effect of salinity on the uptake of cadmium by the common mussel Mytilus edulis (L.). In: McLusky, D. S., Berry, A. J. (ed.) Physiology and behaviour of marine organisms. Proceedings of the 12th European Marine Biology Symposium, Pergamon Press, Oxford, p. 189-193

George, S. G., Coombs, T. L. (1977). The effects of chelating agents on the uptake and accumulation of cadmium by Mytilus edulis. Mar. Biol. 39: 261-268

Gerlach, S. A., Riemann, F. (1973). The Bremerhaven checklist of aquatic nematodes. Veröf. Inst. Meeresforsch. Bremerhaven 4 (Suppl.): 1-404

Haight, M., Mudry, T., Pasternak, J. (1982). Toxicity of seven heavy metals on Panagrellus silusiae; the efficacy of the free-living nematode as an in vivo toxicological bioassay. Nematologica 28: 1-11

Heip, C., Herman, R., Vincx, M. (1984). Variability and productivity of meiobenthos in the southern bight of the North Sea. Rapp. P.-v. Réun. Cons. int. Explor. Mer 183: $51-56$

Hoppenheit, M., Sperling, K. R. (1977). On the dynamics of exploited populations of Tisbe holothuriae (Copepoda, Harpacticoida). IV. The toxicity of cadmium: response to lethal exposure. Helgoländer Meeresunters. 29: 328-336

Howell, R. (1983). Heavy metals in marine nematodes: uptake, tissue distribution and loss of copper and zinc. Mar. Pollut. Bull. 14: 263-268

Jakubczak, E., Delmaere, C., Leclerc, H. (1981). Sensibilité de bacteries du milieu aquatique à quelques substances toxiques. In: Leclerc, H., Dive, D. (ed.) Les tests de toxicité aiguë en milieu aquatique. Inserm, Paris, p. 93-104

Karbe, L. (1972). Marine Hydroiden als Testorganismen zur Prüfung der Toxizität von Abwasserstoffen. Die Wirkung von Schwermetallen auf Kolonien von Eirene viridula. Mar. Biol. 12: 316-328

Lee, D. L., Atkinson, J. H. (1976). Physiology of nematodes. MacMillan Press, London and Basingstoke

Lee, S. S., Mate, B. R., von der Trenck, K. T., Rimerman, R. A., Buhler, D. R. (1977). Methallothionein and the subcellular localization of mercury and cadmium in the Californian sea lion. Comp. Biochem. Physiol. 57 C: 45-53
Lopez, G., Riemann, F., Schrage, M. (1979). Feeding biology of the brackish-water oncholaimid nematode Adoncholaimus thalassophygas. Mar. Biol. 54: 311-318

Mitra, R. S., Gray, R. H., Chin, B., Bernstein, I. A. (1975) Molecular mechanisms of accomodation in Escherichia coli to toxic levels of $\mathrm{Cd}^{2+} \mathrm{J}$. Bacteriol. 121: 1180-1188

Mudry, T., Haight, M., Pasternak, J. (1982). The effects of some heavy metals on the kinetics of pharyngeal pumping in Panagrellus silusiae. Nematologica 28: 12-20

Nimmo, D. R., Lightner, D. V., Bahner, L. H. (1977). Effects of cadmium on the shrimps Penaeus duorarum, Palaemonetes pugio and Palaemonetes vulgaris. In: Vernberg, $F$. J., Calabrese, A., Thurberg, F. P., Vernberg, W. B. (ed.) Physiological responses of marine biota to pollutants. Academic Press, New York, San Francisco, London, p. 131-183

Novick, R. P., Roth, C. (1968). Plasmid-linked resistance to inorganic salts in Staphylococcus aureus. J. Bacteriol. 95 $1335-1342$

Olafson, R. W., Thompson, J. A. J. (1974). Isolation of heavy metal binding proteins from marine vertebrates. Mar. Biol. 28: $83-86$

Patrick, F. M., Loutit, M. (1976). Passage of metals in effluents, through bacteria to higher organisms. Wat. Res. 10: 333-335

Phillips, D. J. H. (1976). The common mussel Mytilus edulis as an indicator of pollution by zinc, cadmium, lead and copper. I. Effects of environmental variables on uptake of metals. Mar. Biol. 38: 59-69

Popham, J. D., Webster, J. H. (1979). Cadmium toxicity in the free-living nematode Caenorhabditis elegans. Environ. Res. 20: 183-191

Ramamoorthy, S., Kushner, D. J. (1975). Binding of mercuric and other heavy metal ions by microbial growth media. Microb. Ecol. 2: 162-176

Reish, D. J., Carr, R. S. (1978). The effect of heavy metals on the survival, reproduction, development and life cycles for two species of polychaetous annelids. Mar. Pollut. Bull. 9 : $24-27$

Samoiloff, M. R. (1973). Nematode morphogenesis: pattern of transfer of protein to the cuticle of adult Panagrellus silusiae (Cephalobidae). Nematologica 19: 15-18

Samoiloff, M. R. (1980). Action of chemical and physical agents on free-living nematodes. In: Zuckerman, B. M. (ed.) Nematodes as biological models. Vol. 2. Aging and other model systems. Academic Press, London, New York, p. 81-98

Samoiloff, M. R., Schulz, S., Jordan, Y., Denich, K., Arnott, E. (1980). A rapid simple long-term toxicity assay for aquatic contaminants using the nematode Panagrellus redivivus. Can. J. Fish. Aquat. Sci. 37: 1167-1174

Sokal, R. R., Rohlf, F. J. (1981). Biometry. The principles and practice of statistics in biological research. W. H. Freeman and Company, San Francisco

Summers, A. O., Silver, S. (1978). Microbial transformations of metals. A. Rev. Microbiol. 32: 637-672

Sunda, W. G., Engel, D. W., Thuotte, R., (1978). Effect of chemical speciation on toxicity of cadmium to grass shrimp, Palaemonetes pugio: importance of free cadmium ion. Envirion. Sci. Technol. 12: 409-413

Theede, H., Scholz, N., Fisher, H. (1979). Temperature and salinity effects on the acute toxicity of cadmium to Laomedea loveni (Hydrozoa). Mar. Ecol. Prog. Ser. 1: $13-19$

Tietjen, J. H., Lee, J. J., Rullman, J., Greengart, A., Trompeter, J. (1970). Gnotobiotic culture and physiological ecol- 
ogy of the marine nematode Rhabditis marina. Limnol Oceanogr. 15: 535-543

Van Damme, D., Heip, C. (1977). Het meiobenthos in de Zuidelijke Noordzee. In: Nihoul, C. F., De Coninck, L. A. P. (ed.) Nationaal Onderzoeks- en Ontwikkelingsprogramma Project Zee. Vol. 7. Inventaris van fauna en flora. Diensten van de Erste minister. Programmatie van het wetenschapsbeleid, p. 1-114

Vranken, G., Heip, C. (1983). Calculation of the intrinsic rate of natural increase, $\mathrm{r}_{\mathrm{m}}$, with Rhabditis marina Bastian, 1865. Nematologica 29; 468-477
Vranken, G., Van Brussel, D., Vanderhaeghen, R., Heip, C. (1984). Research on the development of a standardized ecotoxicological test on marine nematodes. I. Culturing conditions and criteria for two monhysterids Monhystera disjuncta and Monhystera microphthalma. In: Persoone, G., Jaspers, E., Claus, C. (ed.) Ecotoxicological testing for the marine environment. State Univ. Ghent, and Inst. mar. Scient. Res., Belgium, Vol. 2, p. 159-184

Responsible Subject Editor: Dr. G. Lauckner; accepted for printing on June 15, 1985 